Short Communication

\title{
Microscopical Investigation of Sideritis taurica
}

Fatima Kazbekovna Serebryanaya
Irina Konovalova
Department of Pharmacognosy, Botany
and Technology of Phytopreparations,
Pyatigorsk Medical and Pharmaceutical
Institute, Volgograd State Medical
University, Pyatigorsk, North
Caucasian Federal District, Russian
Federation
*email:
f.k.serebryanaya@pmedpharm.ru
Keywords:
Anatomical structure
Diagnostic signs
Flower
Lamiaceae
Morphological and Anatomical
Research
Sideritis taurica
Stem

\begin{abstract}
This research presents the results of the morphological-anatomical study of grass organs above ground (leaves, stems, and flowers) from Sideritis taurica Steph. ex Willd. from the Lamiaceae family. The range of distribution of this species covers Eastern Europe, including Crimea, Caucasus. This plant is commonly found as an ornamental plant and grows in the southern and central regions of Russia. The purpose of this study is the anatomical and morphological study of the vegetative organs of $S$. taurica and the formation of diagnostic signs for reliable plant identification. The research material used was $S$. taurica herbicide samples collected in Crimea on the slopes of Mount Ay-Petri. Plant material is fixed in the glycerin : water system in a ratio of $1: 1$. Cross-section of stems and leaves is carried out using blades. The study was conducted with the morphological-anatomical method. The results obtained indicate the anatomical structure of the lamina, stem, and flower of the plant that has been studied. Anomocytic types of stomatal devices, unicellular and multicellular trichomes, located on the upper and lower sides of the leaf, as well as on the corolla stem and epidermis, have been discovered. The study carried out is part of the $S$. taurica complex pharmacognostic study.
\end{abstract}

Received: July $10^{\text {th }}, 2020$

Accepted: August 19th, 2020

Published: August 31'st, 2020

(c) 2020 Fatima Kazbekovna Serebryanaya, Irina Konovalova. Published by Institute for Research and Community Services Universitas Muhammadiyah Palangkaraya. This is an Open Access article under the CC-BY-SA License (http://creativecommons.org/licenses/by-sa/4.0/). DOI: https://doi.org/10.33084/bjop.v3i3.1524

\section{INTRODUCTION}

Sideritis taurica Steph. ex Willd. is a medicinal plant known since the ancient centuries and used in folk medicine in many countries. The Crimean ferruginous essential oil has antibacterial and antiprotozoal activity (Aboutabl et al., 2002; Fraga, 2012). The plant has antihypertensive, diuretic properties, promotes wound scarring, and helps with tumors (Aboutabl et al., 2002; Aboutabl et al., 2009; Navarro et al., 1997). The word "Sideritis" can be translated from Greek as "one who is iron or possesses iron." The plant was known to Dioscorides and Theophrastus (Navarro et al., 1997).

The distribution range of this species covers Eastern Europe, including Crimea, the Caucasus. Crimean iron can be found on rocky steppe slopes, showers, and outcrops of limestone, on pastures, grows on Crimean mountain pastures, often found on Demerji and ChatyrDag (Navarro et al., 1997). Species of the genus are widely used in the Mediterranean region in folk medicine for their antimicrobial, anti-inflammatory, and antioxidant properties (de las Heras et al., 1994; Cabrera et al., 1983).

Sideritis species are commonly used to treat the target, as well as herbal teas and flavors (Kirimer et al., 2003). In rural areas, they even like more than salvia species like tea. Moreover, glandular species as tea infusions are widely known for improving memory function and cognitive ability (Hofrichter et al., 2017). The extracts and fractions showed significant analgesic, antiinflammatory, antiulcerogenic, and antihyperglycemic activity, but showed no anticonvulsant and antipyretic 
effect than control groups and control drugs (Kilic et al., 2020; Villar et al., 1984). Apart from S. taurica, there are more than 150 species within the genus Sideritis, among which S. ajpetriana Klokov, S. atrinervia Juz., S. augustinii Sennen \& Pau., S. balansae Boiss., S. catalaunica Sennen \& Pau., S. catillaris Juz., S. chlorostegia Juz., S. ciliata Thunb., S. comosa (Rochel ex Benth.) Stankov., S. conferta Juz., S. curvidens Stapf., S. cypria Post., S. endressii Willk., S. euxina Juz., S. florida Boiss. \& Heldr., S. hirsuta L., S. hyssopifolia L., S. imbrex Juz., S. incana L., S. marschalliana Juz., S. montana L., S. ocymastrum L., S. perfoliata L., S. purpurea Talbot ex Benth., S. raeseri Boiss. \& Heldr., S. romana L., S. scardica Griseb., S. scythica Juz., and S. syriaca L. (Galushko, 1980). Extracts and components of $S$. taurica have antiinflammatory, anti-rheumatic, anti-ulcer, insecticidal, antimicrobial, antioxidant, and cytotoxic activity (Baser et al., 1996; Basile et al., 2006; Ertaş et al., 2009; Ezer et al., 1994; Uğur et al., 2004).

Diterpenoids are among the most common and essential pharmacological interests of the classes of natural compounds presented in S. taurica. Leaves, stems, and flowers contain iridoids. Fatty oil 29-30\% was found in the seeds, in its composition acids: palmitic, stearic, oleic, linoleic, linolenic. Crimean Sideritis is considered a natural immunomodulator. The essential oil composition of $S$. taurica was studied; the main components of a-bisabolol and a-pinene were isolated (Aljančić et al., 1996; Ellman et al., 1961). The determination of flavonoids in the genus Sideritis is described by a novel reverse-phase high-performance liquid chromatography method. The content of ethyl acetate extract of sixteen species of the genus Sideritis in chrysoeriol, apigenin, sideritoflavone, xanthomycrol, gardenin D, 8-methoxycyrsilineol, and desmethylnobiletin is reported (Palomino et al., 1996).

Various studies related to $S$. taurica have been widely reported before, although most of them were reported over the last 20 years. Interestingly, there are barely any studies reporting microscopic studies of these plants. Therefore, this study tries to complete the missing puzzle from $S$. taurica research by conducting an in-depth investigation of the plant's microscopic study. This study aimed to provide information regarding the diagnostic features of both the vegetative and generative organs of S. taurica.

\section{MATERIALS AND METHODS}

Morphological and anatomical study of vegetative and generative organs of $S$. taurica. The plant material was fixed in the system to carry out a micromorphological study : glycerin - water in a ratio of $1: 1$. Transverse sections of the leaf plate and stem were made manually using blades. During the experiment, temporary preparations were used. Anatomical studies were carried out using a microscope. Our sample was collected in Crimea on Mount Ay-Petri's slopes on July 27th, 2018. As an ornamental plant, it is grown in the southern regions and the middle strip of Russia as shown in Figure 1. The results of microscopic observations of all plant incisions are then documented in a figure using a camera. If the cellular parts of the organ are not clearly visible, documentation is carried out using handwritten drawings according to the original results.

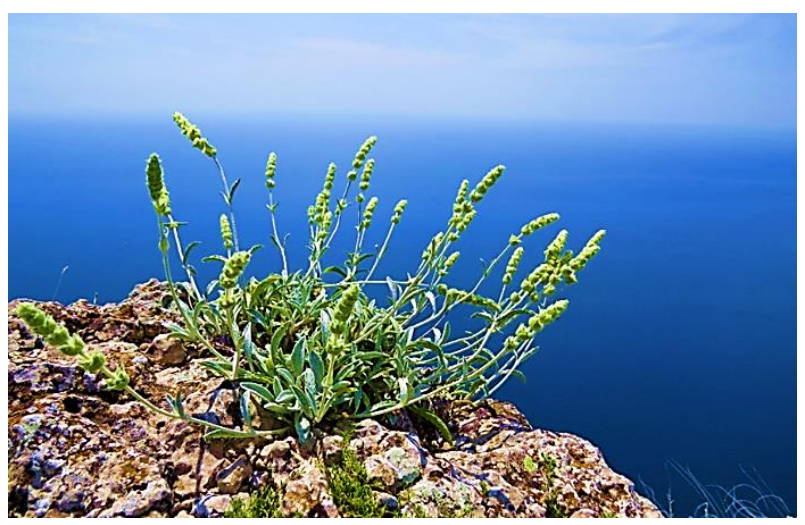

Figure 1. The location of S. taurica on Mount Ay-Petri, Crimean Peninsula 


\section{RESULTS AND DISCUSSION}

\section{Morphological investigations}

Sideritis taurica is a perennial herb with a stem densely covered with felt hairs and woody at the base. Flowerbearing shoots are usually several; in addition to them, there are several shortened, non-flowering shoots. The flowers are pale yellow, collected in a dense corolla. There are several one-year-old ascending, rosette-shaped shoots. Stem leaves are triangular-lanceolate in shape. Bracts are whole-marginal, heart-shaped or triangular, parched, gray, green or green-yellow, felt-pubescent. The inflorescence is spike-shaped, elongated, dense, or intermittent in the lower part. The corolla is light yellow, noticeably longer than the calyx $(8-14 \mathrm{~mm})$. Calyx with five identical sepals. Fruit disintegrating into four singleseeded nuts. The collected $S$. taurica plant samples were then made into a dry herbarium for storage, as shown in

\section{Figure 2 .}

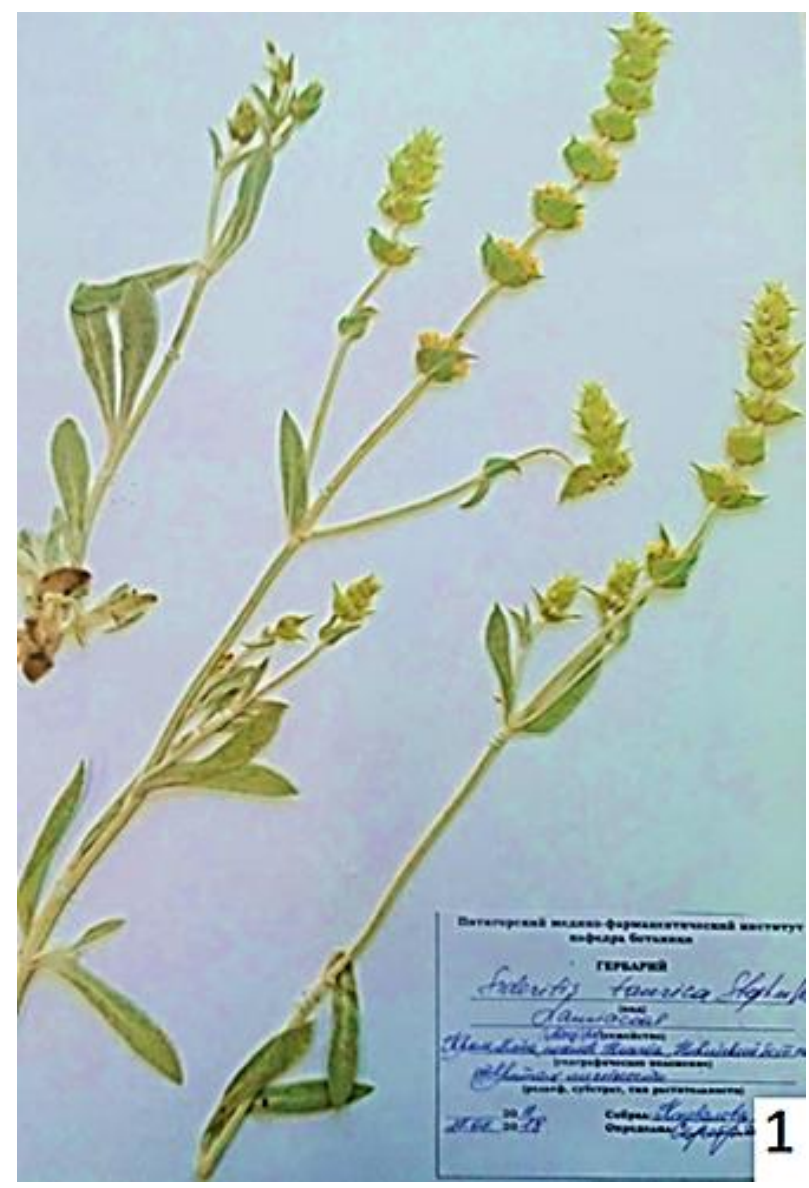

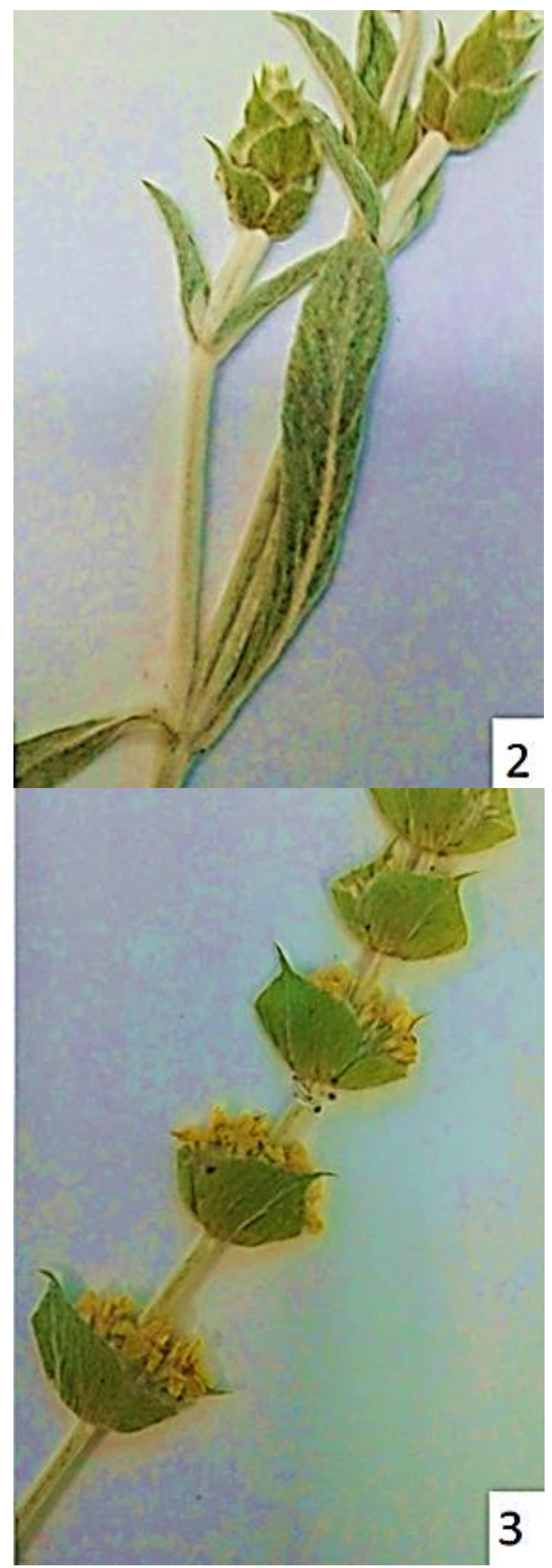

Figure 2. Herbarium sample fragments of S. taurica; (1) lifeform, (2) leaves, (3) inflorescences 


\section{Micromorphological investigations}

The stem has a tetrahedral shape on a transverse section (Figures 3-1A-3-1B). The epidermis represents the cover tissue; on it, there are multicellular trichomes and simple ones. There is one layer of tightly closed cells; the cells are rectangular in round shape. Collenchyma of the plate type consists of several layers of living large cells. There are 2-3 layers of living thin-walled cells represent the performing parenchyma. They are located in the form of a ring, with dead cells of a rectangular shape. The tissues included in the bark are represented by chlorenchyma and parenchyma. The central cylinder includes phloem, cambium, xylem, core parenchyma. The core is formed by multifaceted living cells tightly adjacent to each other. A continuous ring of sclerenchyma fibers represents the pericycle (Figure 3-1C).

The dorsoventral type's leaf blade consists of cover tissue, mesophyll, and vascular bundles (Figures 3-2A - 3-2B). The cover tissue-epidermis is represented by one layer of epidermal cells, covered with a cuticle layer on the outside. The conductive system is represented by one collateral vascular bundle located in the middle (Figure 3-2C). Xylem is represented by vessels and parenchyma: phloem sieve tubes and cell companions. We also discovered mechanical elements represented by angled collenchyma and sclerenchyma. Sclerenchyma adjoins the lower side of the conducting beam (Figure 3-2D).

The upper epidermis of the leaf is represented by the primary cells and stomatal apparatus. Trichomes are located along the entire part of the sheet plate and are represented by multicellular and unicellular hairs. The cells are winding, different in shape, alive, with thickened outer walls. Under the upper epidermis in the main vein area is the angular type's collenchyma, located in one layer under the upper and lower epidermis (Figures 33A -3-3C).

Wavy anticlinal cell walls characterize the lower epidermis, and the lower epidermis is represented by primary cells with highly tortuous anticlinal walls. The trichomes are formed by simple multicellular cells with characteristic extended junction sites between cells in the form of anastomoses. Besides, there are two types of glandular hairs (Figures 3-3D, 3-4D - 3-4E).

Stomatal apparatuses are present on both sides of the leaf blade. They have a diacytic type, which is characteristic of representatives of the spongy family, including the genus glandular. The epidermis' primary cells differ in the degree of tortuosity of the anticlinal walls (Figures 3-4A3-4B).

The epidermis of the flower's calyx is similar in structure to the lower epidermis of the leaf plate, characterized by tortuous epidermal cells, diacytic stomata, and numerous trichomes in the form of head and simple multicellular hairs with characteristic expansion in the cell junction zone (Figures 3-5A - 3-5C).

The corolla epidermis is characterized by rectangular or polyhedral elongated cells, with a thickened cell wall, trichomes are absent (Figures 3-6A - 3-6C). Stomata are absent also. Microscopical Investigation of $S$. taurica has never been reported before, so this study's results are expected to complement the research data related to $S$. taurica. 


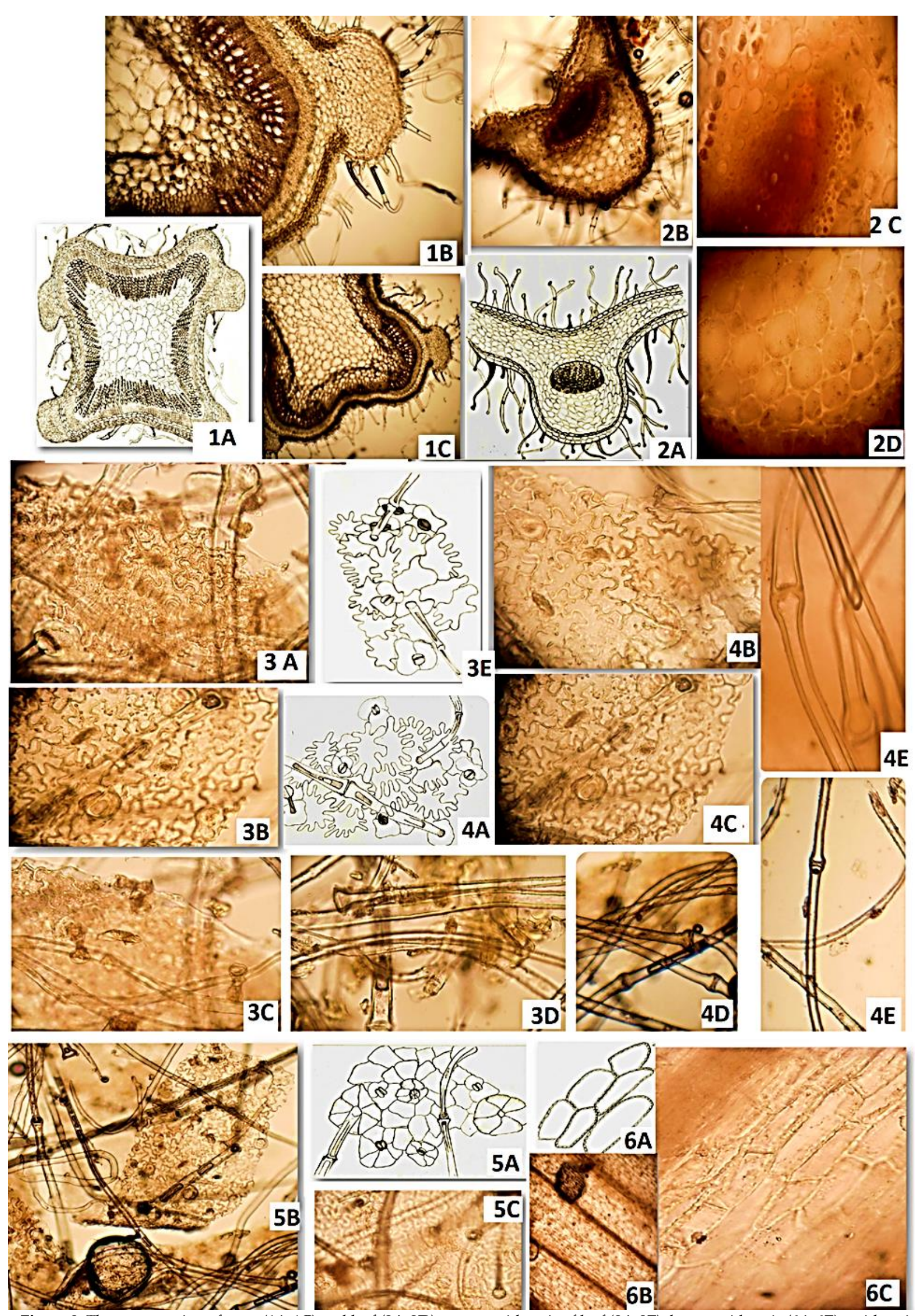

Figure 3. The cross-section of stem (1A-1C) and leaf (2A-2D), upper epidermis of leaf (3A-3E), lower epidermis (4A-4E), epidermis of calice (5A-5C), and epidermis of the corolla (6A-6C) of $S$. taurica. 
Sideritis taurica itself is still quite widely researched, especially in relation to the various metabolites' pharmacological activity (Aneva et al., 2019; Tunalier et al., 2004). Fatty acids, hydrocarbons, a-amyrin, stigmasterol, and $\beta$-sitosterol were identified in the $n$ hexane extract of the air portions of $S$. taurica. Analysis of GC-FID and GC/MS showed that the two oil samples were identical in composition but differed in percentages of some components. The composition of essential oils of the species was investigated by HA and GC mass spectrometry. They were characterized by the presence of a high percentage of monoterpene hydrocarbons (Kirimer et al., 2003; Ezer et al., 1996).

Monoterpene hydrocarbons were mainly $\beta$-pinene and a-pinene. The main sesquiterpene hydrocarbons were aromadendrene and a-cubeben. The main oxygencontaining monoterpenes were a-terpineol and transpinocarveol; while the main oxygen-containing sesquiterpenes were a-cadinol, curcumenol, and abisabolol. Two oil samples exhibited significant antitumor activity against Allolobophora caliginosa, supporting recommendations on the possible utility of $S$. taurica oil as an antitumor agent and testing the correlation between the increased antitumor activity of essential oil with its high oxygen content (Navarro et al., 1997; González-Burgos et al., 2013; Ezer et al., 1996).

Studies related to the microscopical investigation of a medicinal plant itself are generally carried out on a plant that is well known for its pharmacological activity and its various secondary metabolites (Ketjarun et al., 2016). In addition to the purposes of identifying and authenticating medicinal plants (Song et al., 2020), micromorphological investigations will also provide detailed information if there are differences at the microscopic level of several different plant species and sub-species but still in the same genus and has never been identified before (Jachula et al., 2018; Konarska, 2017).
Related studies of the genus Sideritis have previously been reported by Türkmenoğlu and Duman (2015) as well as Rejdali (1991), but have never been carried out on S. taurica. Thus, the results of this study will provide novelty for the development of various studies on $S$. taurica and other plants from the genus Sideritis.

\section{CONCLUSION}

The micromorphological study of vegetative and generative organs of $S$. taurica were reported for the first time. The diagnostic features were established for reliable identification of the plant, such as the trichomes represented by simple unicellular and multicellular hairs; a beam type conductive system; hairs located in the structure of both epidermis of the leaf, as well as on the epidermis of the stem and calices, but not specialized for the epidermis of the corolla.

\section{REFERENCES}

Aboutabl, E., A., Nassar, M.I., Elsakhawy, F.M., Maklad, Y.A., Osman, A.F., \& El-Khrisy, E.A.M. (2002). Phytochemical and pharmacological studies on Sideritis taurica Stephan ex Wild. Journal of Ethnopharmacology, 82(2-3), 177-184. doi:10.1016/S0378-8741(02)00172-1

Aboutabl, E., A., Meselhy, K.M., \& El-Azzouny, A.M. (2009). Composition and Antiwormal Activity of Essential Oil from Sideritis taurica Stephan ex Willd Grown in Egypt. Journal of Essential Oil Research, 21(1), 94-96. doi:10.1080/10412905.2009.9700121

Aljančić, I., Macura, S., Juranic, N., Andjelkovic, S., Randjelovic, N., \& Milosavljevic, S. (1996). Diterpenes from Achillea clypeolata. Phytochemistry, 43(1), 169-171. doi:10.1016/0031-9422(96)00271-3

Aneva, I., Zhelev, P., Kozuharova, E., Danova, K., Nabavi, S.F., \& Behzad, S. (2019). Genus Sideritis, section Empedoclia in southeastern Europe and Turkey - studies in ethnopharmacology and recent progress of biological activities. DARU Journal of 
Pharmacentical Sciences, 27(1), 407-421. doi:10.1007/s40199-019-00261-8

Baser, K.H.C., Bondi, M.L., Bruno, M., Kirimer, N., Piozzi, F., Tumen, G., \& Vassalo, N. (1996). An entkaurane from Sideritis huber-morathii. Phytochemistry, 43(6), 1293-1295. doi:10.1016/S0031-9422(96)00371-8

Basile, A., Senatore, F., Gargano, R., Sorbo, S., Del Pezzo, M., Lavitola, A., Ritieni, A., Bruno, M., Spatuzzi, D., Rigano, D., \& Vuotto, M.L. (2006). Antibacterial and antioxidant activities in Sideritis italica (Miller) Greuter et Burdet essential oils. Journal of Ethnopharmacology, 107(2), 240-248. doi:10.1016/j.jep.2006.03.019

Cabrera, E., García-Granados, A., de Buruaga, A.S., \& de Buruaga, J.M.S. (1983). Diterpenoids from Sideritis hirsuta subsp. Nivalis. Phytochemistry, 22(12), 2779-2781. doi:10.1016/S00319422(00)97695-7

Ellman, G.L., Courtney, K.D., Andres, V., \& Featherstone, R.M. (1961). A new and rapid colorimetric determination of acetylcholinesterase activity. Biochemical Pharmacology, 7(2), 88-90. doi:10.1016/0006-2952(61)90145-9

Ertaş, A., Oztürk, M., Boğa, M., \& Topçu, G. (2009). Antioxidant and anticholinesterase activity evaluation of ent-kaurane diterpenoids from Sideritis arguta. Journal of Natural Products, 72(3), 500-502. doi:10.1021/np800671p

Ezer, N., Vila, R., Cañigueral, S., \& Adzet, T. (1996). Essential oil composition of four Turkish species of Sideritis. Phytochemistry, 41(1), 203205. doi:10.1016/0031-9422(95)00601-X

Ezer, N., Usluer, G., Güneş, İ, \& Erol, K. (1994). Antibacterial activity of some Sideritis species. Fitoterapia, 65, 549-551.

Fraga, B.M. (2012). Phytochemistry and chemotaxonomy of Sideritis species from the Mediterranean region. Phytochemistry, 76, 7-24. doi:10.1016/j.phytochem.2012.01.018

Galushko, A.I. (1980). Flora of the Northern Caucasus: A field guide Vol. 2. Rostov-na-Donu, Russia: Rostov University. pp. 1978-1980.

González-Burgos, E., Carretero, M.E., \& GómezSerranillos, M.P. (2013). Kaurane diterpenes from Sideritis spp. exert a cytoprotective effect against oxidative injury that is associated with modulation of the Nrf2 system. Phytochemistry, 93, 116-123. doi:10.1016/j.phytochem.2013.03.017

de las Heras, B., Vivas, J.M., \& Villar, A. (1994). Antiinflammatory activity of Sideritis javalambrensis extracts. Journal of Ethnopharmacology, $\quad 41(1-2), \quad$ 15-17. doi:10.1016/0378-8741(94)90053-1

Hofrichter, J., Krohn, M., Schumacher, T., Lange, C., Feistel, B., Walbroel, B., \& Pahnke, J. (2016). Sideritis spp. Extracts Enhance Memory and Learning in Alzheimer's $\beta$-Amyloidosis Mouse Models and Aged C57Bl/6 Mice. Journal of Alzheimer's Disease, 53(3), 967-980. doi:10.3233/JAD-160301

Jachula, J., Konarska, A., \& Denisow, B. (2018). Micromorphological and histochemical attributes of flowers and floral reward in Linaria vulgaris (Plantaginaceae). Protoplasma, 255(6), 1763-1776. doi:10.1007/s00709-0181269-2

Ketjarun, K., Staples, G.W., Swangpol, S.C., \& Traiperm, P. (2016). Micro-morphological study of Evolvulus spp. (Convolvulaceae): the old world medicinal plants. Botanical Studies, 57, 25. doi:10.1186/s40529-016-0141-y

Kilic, T., Topcu, G., Goren, A.C., Aydogmus, Z., Karagoz, A., Yildiz, Y.K., \& Aslan, I. (2020). Ent-kaurene Diterpenoids from Sideritis lycia with Antiviral and Cytotoxic Activities. Records of Natural Products, 14(4), 256-268. doi:10.25135/rnp.163.19.08.1373

Kirimer, N., Tabanca, N., Özek, T., Baser, K.H.C., Tümen, G., \& Duman, H. (2003). Composition of Essential Oils from Five Endemic Sideritis Species. Journal of Essential Oil Research, 15(4), 221-225. doi:10.1080/10412905.2003.9712125

Konarska, A. (2017). Comparative micromorphology and anatomy of flowers and floral secretory structures in two Viburnum species. Protoplasma, 254(1), 523-537. doi:10.1007/s00709-016-0972-0

Navarro, A., de las Heras, B., \& Villar, A.M. (1997). Andalusol, a diterpenoid with antiinflammatory activity from Sideritis foetens Clemen. Zeitschrift fur Naturforschung. C, 
Journal of Biosciences, 52(11-12), 844-849. doi:10.1515/znc-1997-11-1219

Palomino, O.M., Gomez-Serranillos, P., Carretero, E., \& Villar, A. (1996). High-performance liquid chromatography of flavonoids from Sideritis species. Journal of Chromatography A, 731(1-2), 103-108. doi:10.1016/0021-9673(95)01232-X

Rejdali, M. (1991). Leaf micromorphology and taxonomy of North African species of Sideritis L. (Lamiaceae). Botanical Journal of the Linnean Society, 107(1), 67-77. doi:10.1111/j.10958339.1991.tb00215.x

Song, J.H., Yang, S., \& Choi, G. (2020). Taxonomic Implications of Leaf Micromorphology Using Microscopic Analysis: A Tool for Identification and Authentication of Korean Piperales. Plants, 9(5), 566. doi:10.3390/plants9050566

Tunalier, Z., Kosar, M., Ozturk, N., Baser, K.H.C., Duman, H., \& Kirimer, N. (2004). Antioxidant Properties and Phenolic Composition of Sideritis Species. Chemistry of Natural Compounds, 206-210. doi:10.1023/B:CONC.0000039124.83109.ac

Türkmenoğlu, F.P. \& Duman, H. (2015). Comparative Morphological Investigations on Three Related Sideritis L. Species Belonging Section Empedoclia(Rafi n) Bentham. Hacettepe University Journal of the Faculty of Pharmacy, 35(1), 87-101.

Uğur, A., Varol, O., \& Ceylan, O. (2005). Antibacterial Activity of Sideritis curvidens. and Sideritis lanata. from Turkey. Pharmaceutical Biology, 43(1), 47-52. doi:10.1080/13880200590903354

Villar, A., Gasco, M.A., \& Alcaraz, M.J. (1984). Antiinflammatory and anti-ulcer properties of hypolaetin-8-glucoside, a novel plant flavonoid. Journal of Pharmacy and Pharmacology, 36(12), 820-823. doi:10.1111/j.2042-7158.1984.tb04884.x 